\title{
Social Entrepreneurship Andragogy-Based for Community Empowerment
}

\author{
Dayat Hidayat \\ Nonformal Education Department Faculty of Teachers Training and Education \\ University of Singaperbangsa Karawang, hidayat.unsika@gmail.com
}

\begin{abstract}
The essence of social entrepreneurship is the ability to initiate, lead and implement problem-solving strategies, through cooperation with others in all types of social networks. The purpose of this study analyzes: 1) entrepreneurship training, 2) adult education assumptions, and 3) community empowerment. This study is discussed by using a comparative theory analysis method that related to entrepreneurship training, andragogy, and community empowerment from various literary sources. Analysis is conducted to find conclusions that can be justified scientifically. The results of the study conclude that: 1) social entrepreneurship training is an organized learning process from planning, implementation, and evaluation on non-formal education path aimed at enhancing community knowledge, attitude and skills for learning and endeavor, 2) entrepreneurship training based on andragogy conducted through a learning process that implements adults' assumptions of selfconceptual, learning experiences, learning readiness, and learning orientation. 3) Community empowerment is a process of empowerment or strength to community to have the ability of individuals who completely agreed with the community in building social and economic empowerment of the community.
\end{abstract}

Keywords: Entrepreneurship training, Adult education, Community empowerment.

\section{Introduction}

Nowadays, almost all institutions, both government and private, are aware of the condition of limited human resources in facing rapidly changing technological changes. Education and training is a learning process aimed at developing human resource capacity, so that it can cope with the changing needs of the community for new technologies.

Education is a process of developing human capabilities in the direction of an organization or institution. While training is part of the educational process that aims to improve the skills or special skills of a person or group of people. In general, training is part of education that describes a learning process. Training is a learning process that aims to improve the knowledge, attitude, skills, and performance of individuals in organizations, institutions or companies. Training programs are designed to improve performance at the 
individual, group and/or organizational level. Improved performance will show changes that occur within individuals, groups and/or organizations that are measurable in their knowledge, skills, skills, attitudes and social behavior. Various training programs are widely implemented to meet community needs, including social entrepreneurship training.

Entrepreneurship training is the learning process of learning the science of one's values, abilities and behaviors in facing life's challenges and for opportunities with risks that may be faced. In the business field, Zimmerer, T.W. (1996) argued that entrepreneurship is the result of a discipline and a systematic process of applying creativity and innovation in meeting the needs and opportunities in the market.

Training of social entrepreneurship andragogy-based is a learning process that applies adult learning principles. Andragogy or adult education is formulated as a science and art to help adults learning. Andragogy focuses on improving adult life, providing the skills and ability to solve the problems experienced in the life of society.

One of the goals of training of social entrepreneurship andragogy-based is to improve community empowerment. Community empowerment is an effort to increase the ability of the community (poor, marginal, marginalized) to express their opinions and/or needs and actively participate in managing the community institutions for the improvement of their lives.

The problem that is often faced in developing entrepreneurship is the lack of entrepreneurship programs that apply the principles of andragogy learning. Entrepreneurship development is less in line with self-concept, learning experience, learning readiness, and adult learning orientation. In its essence, adults have a self-concept that has been independent. But in the development of entrepreneurship programs are less appropriate in learning atmosphere, diagnosis of learning needs, and adult business planning process.

Adults have a learning experience in accordance with the passage of time to grow and develop toward maturity. But in entrepreneurship practice is not based on adult experience in developing a business. Adults also have learning readiness, so the development of entrepreneurial materials needs to be adjusted between the learning needs and the adult endeavor with its social role.

Adults also have a learning orientation, so have a tendency in developing entrepreneurship centered on solving problems are faced (problem centered orientation). Therefore, the development of entrepreneurship for adults should be practical and can be applied immediately in daily life.

Based on above background, the social entrepreneurship program needs to be developed in accordance with the principles of learning based on andragogy. Through social entrepreneurship based on andragogy; Knowledge, skills and entrepreneurial attitudes of society will increase in accordance with self-concept, learning experience, readiness of study and adult learning orientation to improve community empowerment and economic well-being of his life.

\section{Method}

This study is discussed by using a comparative theory analysis method that related to entrepreneurship training, andragogy, and community empowerment from various literary sources. Analysis is conducted to find conclusions that can be justified scientifically. This study used analytical research methods that investigate concepts through theoretical analysis. The researchers identified, studied and then cataloged the data to gain an understanding of the concept of social entrepreneurship, andragogy, and community empowerment that can be observed directly or indirectly. The theoretical concept is the main data. The researcher interprets the data and facts to get an explanation of the concepts 
of social entrepreneurship, andragogy, and the empowerment of collecting societies precisely and clearly to draw conclusions. The technical data analysis used is an interactive model through the stages of data collection, data reduction, display data, and conclusion/verifying.

\section{Discussion}

\subsection{Social Entrepreneurship Training}

In general, training is part of education that describes a process. Quite a lot of understanding and limitations of training that we can get from experts with different point of view. Training is a formal procedure facilitated by learning to improve behavioral changes related to improving the goals of the institution or organization. Mayo \& DuBois (1987:5) argue that training and education have many similarities. Learning in the educational process is more comprehensive, broad, and builds capabilities of a general nature. While learning in training is more specific, task-oriented, and applicative.

Laird, D. (1985:11) describes training as an activity to improve human performance on working that is currently being worked or is being employed to do. Nedler, L. (1982) defines training as a learning process to improve the performance of people in completing work.

Training programs are expected to increase knowledge, attitudes, and skills of human resources as an important asset in the institution. Increasing knowledge, attitudes, and skills through training programs are expected to improve institutional performance of external change and competition. Robinson, K.P. (1981:12) states about training as a way of learning or experience to develop a person's behavior patterns in the areas of knowledge, skills or competencies to achieve the desired standards.

Entrepreneurship training is an organized learning process from planning, implementation, and evaluation on non-formal education channels aimed at improving community knowledge, attitude and skills for learning and working. Zimmerer, T.W. (1996:51) defines entrepreneurship as applying creativity and innovation to slove the problems and to the exploits of that people face everyday. Entrepreneurship is a combination of creativity, innovation, and courage to face the risks involved by working hard to form and maintain new business. Creativity is 'thinking new things' while innovation is 'doing new things'. So the success of entrepreneurship will be achieved if thinking and doing something new or something old done in a new way (Levitt quoted by Zimmerer, T.W. 1996:51).

Entrepreneurship is an ability in creative thinking and innovative behavior that is used as the basis, resources, driving force, goals, strategies, tips, and processes in the face of life challenges. Meredith, G.G. (1996:9) argues that entrepreneurship means integrating personal character, finances and resources.

Various public entrepreneurship programs have developed very rapidly, including social entrepreneurship. Ontologically, there is no consensus about the precise definition of the definition of social entrepreneurship. According to Borganza et al. (2010) defining social entrepreneurship is a challenge in itself. Nicholls (2006) defines social entrepreneurship in the context of a blend of nonprofit organizational management and commercial firms run by businesspeople, charities, and social drivers.

Epistimologically, Renko et al. (2009) analyzed the effect of entrepreneurial orientation on product innovation and capital investment. According to him entrepreneurship orientation is an important factor that positively influences product innovation and capital investment. While $\mathrm{Wu}$, et al. (2008) analyzed the intellectual 
impact of capital, including the entrepreneurial orientation, on corporate innovation and found that the moderating effects of entrepreneurial orientation outweigh other intellectual variables of capital.

Axiologically, the study of social entrepreneurial literature contributes to community communities and local governments. Bornstein (2007) argues that the most serious problem of social entrepreneurship is the limited financial resources and the lack of qualified human resources. As a result, many developing country governments have doubts that this entrepreneurial application can work (Borganza, et al., 2010). In its development, the application of social entrepreneurship differs across countries, even among developing countries in Asia (Defourny and Kim, 2011).

Entrepreneurship training has evolved an an important study in the research and development entrepreneurial paradigms related to the study of entrepreneurial academic studies and practical development for new entrepreneurs, but the research is still rare and not much understood well (Deakins, 2000). Entrepreneurship itself is a leaner, who constanly explores the successfull desires of his life journey (Franco and Haase, 2009). The essence of social entrepreneurship involves nonprofit business activities, business activities for social purposes, and combination of both, but for social purposes.

\subsection{Andragogy Concepts and Assumptions}

Andragogy is often interpreted as an art and science that helps adults to learn (the art and science of helping adult learn). Etymologically, the term andragogy means the study of how adults learn. The definition is in line with the thinking of Knowles (1970) which states that andragogy as the art and science to help adult a learner.

Furthermore, Darkenwald and Merriam (1982) express the notion of adult education is a process where by person of social roles characteristic of adult status undertake systematic and sustained learning activities for the purpose of bringing about chnges in knowledge, attitudes, values, or skills.

Andragogical assumptions consist of self-concept, learning experience, learning readiness, and adult learning orientation. Knowles (1970) in developing the four principal assumptions andragogi concept as follows:

\subsubsection{Self Concept}

The assumption is that adults have their own self-concept. Because of this independence, adults need the rewards of others as self-determining humans, self-directed. This has implications for the implementation of training programs, particularly those related to climate and learning atmosphere and needs diagnosis and training planning process.

\subsubsection{Learning Experience}

The assumption is that according to the passage of time adults have grown and progressed towards maturity. Therefore, in adult training or adult technology, there is a decrease in the use of transmittal techniques such as those used in conventional training and to further develop experiential techniques. In this case it is known as "experiential learning cycle". This has implications for the selection and use of adult training methods and techniques. In training practice more use of group discussion, brainstorming, laboratory work, field school, practice and so on, which basically seeks to involve the participation of trainees. 


\subsubsection{Readiness to Learn}

The assumption is that every individual is getting matured according to the passage of time, then learning readiness is not determined by academic or biological necessity or coercion, but more determined by the demands of development and change of task and social role. This brings implications to the learning materials in a particular training. In this case of course learning materials need to be tailored to the needs in accordance with its social role.

\subsubsection{Orientation Learning}

The assumption is that in adults have a tendency to have a learning orientation centered on solving problems faced. The implications for the nature of learning materials or training for adults, namely that the material should be practical and can be applied immediately in everyday reality.

Based on the above assumptions, it can be concluded that entrepreneurship training based on andragogy considers the principle of learning for adults. Entrepreneurship training is conducted in accordance with the learning needs, experience, readiness, and objectives of adult learning to develop their business.

\subsection{Community Empowerment}

Word Bank (2001) defines empowerment as an effort to provide opportunities and capabilities to the poor to be able to voice and voice opinions, ideas and ideas, and the ability and courage to choose something (concepts, methods, products, actions and others) is best for the person, the family, and the community. Community empowerment is a process of improving the ability and attitude of community self-reliance.

The main approach in the concept of community empowerment is that the subject of its own development efforts. Schneider (1999) states that: empowerment goes well beyond the narrow realm of polotical power, and differs from classical definition of power by Max Weber.

Rappaport (Weissberg, 1999) suggests that empowerment is viewed as a process: the mechanism by which people, organization and communities gain mastery over their lives. Hacker (1999) mentions empowerment may be understood as a process of transformation. This includes the tranformations of the unequal power relationship, unjust structures of society, and development policies. Empowerment is a way that people, communities, and organizations are directed to be able or powerful over their lives (Rappaport, 1984).

Freire (1972) defines empowerment in the field of education as a practice of selfliberation from ignorance, pressures, and other things that imprison a person and or community to improve his life.

\section{Conclusion}

Social entrepreneurship training is an organized learning process from planning, implementation, and evaluation on non-formal education channels aimed at improving community knowledge, attitude and skills for learning and working. Andragogy is a science or art that learns adult learning. Andragogical assumptions consist of self-concept, learning experience, learning readiness, and adult learning orientation. Community empowerment is a process of empowerment or strength of community to have the ability in building social and community economic empowerment. 


\section{References}

1. Bornstein, D. How to Change the World: Social Entrepreneur and the Power of New Ideas, Updated Edition, New York, Oxford University Press, (2007)

2. Borganza, C. Depedri, S. dan E, Tortia. The Growth of Organizational Variety in Market Economies, The Cs. of Soc. Ent. Eur. Wrk. Pap. J. 03, 10. (2010)

3. Darkenwald, G D., and Merriam, Sharan B. Adult Education: Foundations of Practice, New York, Harper and Row, Publishers, (1982)

4. Deakins, D. and Freel, M. Entrepreneurial learning and the growth process in SMEs, The Lrn. Org. 5, 3. 144-155. (1998).

5. Defourny, J. dan Kim, S. Emerging. Models of Social Enterprise in Eastern Asia: a Cross-Country Analysis. Soc. Ent. J. 7, 1. 86-111. (2011)

6. Franco, M dan Haase, K. Entrepreneurship: an organisational learning approach. J. of Smll. Buss. and Ent. Dev. 16, 4. 628-641. (2009)

7. Freire, P., The Pedagogy of The Oppressed, New York, Herder and Herder, (1972)

8. Hacker, H., Empowerment Projects for and by Women, Summary of Pilot Study DED Yaounde, (Unpublished), (1999)

9. Knowles, M., Informal Adult Education: A Guide for Administrator, Leader and Teachers, New York, Association Press, (1950)

10. Laird, D., Approach to Training and Development, New York, Addison-Wesley Publising Company, (1985)

11. Mayo, G.D. \& DuBois, P.H., The Complete Book of Training: Theory, Prinsiples, and Techniques, San Diego, CA University Associaties, Inc., (1987)

12. Meredith, G., Kewirausahaan, Teori dan Praktek, Jakarta, PT. Pustaka Binaman Pressindo, (1996)

13. Nadler, L., Designing Training Program, The Critical Events Model, Sidney, Addison Wesley Publishing Company, (1982)

14. Nicholls, A. The New Social Entrepreneurship. What Awaits Social Entrepreneurial Ventures? Eql. Opp. Int. 26, 7. 729-732. (2006)

15. Rappaport, J., Studies in Empowerment: Introduction to the Issue, Prevention in Human Issue, USA, (1984)

16. Renko, M., Carsrud, A., dan Brannback, M. The Effect of a Market Orientation, Enterpreneurial Orientation, and Technological Capability on Innovativeness: A study of Young Biotechnology Ventures in the United States and in Scandinavia. J. of Smll. Buss. Mgmt. 47, 3. 331-369. (2009)

17. Robinson, K.P., A Handbook of Training Management, London, Kogan Page Ltd, (1981)

18. Schneider, Participatory Governance: The Missing Link for Poverty Reduction. OCECD Develompment Center, Policy Brief No 17. Paris, (1999)

19. Srinivasan, L., Perspectives on Nonformal Adult Learning: Functional Education for Individual, Community and National Development, Connecticut Prentice Hall, (1977)

20. Wu, W., Chang, M., and Chen, C. Promoting Innovation through the Accumulation of Intellectual Capital, Social Capital, and Enterpreneurship Orientation. R\&D Mgmt. 38, 3. 265-277. (2008)

21. Weissberg, R., The Policies Empowerment, Praeger, Westport, Connecticut and London, (1999)

22. World Bank, Sustainable Development in the 21 Century, (2001)

23. Zimmerer, T. W., \& Norman, M. S., Entrepreneurship And The New Venture Formation, New Jersey, Prentice-Hall International, Inc., (1996) 